\title{
TECHNOLOGY AND RELATIONSHIPS IN THE GUIDANCE CONTEXT: AN ARTICLE BASED ON A STUDY OF SUSTAINABLE RELATIONSHIPS IN GUIDANCE SITUATIONS BETWEEN TEACHERS AND STUDENTS IN HIGHER EDUCATION
}

\author{
Elin Birkeland Markestad \\ Inland University of Applied Sciences, Norway \\ Bjørg Herberg Gloppen \\ Inland University of Applied Sciences, Norway
}

\begin{abstract}
As teacher educators and mentors, we have long been concerned with establishing an effective guidance tradition among our students and in this way ensuring that each individual student takes care of his/her professional and personal growth. We need more knowledge of what is necessary for guidance to be perceived as meaningful, and thus we must facilitate students' acquisition of knowledge about guidance. Sustainable relationships between teachers and students are needed, and we must consider how modern technology may be used in an effective and appropriate manner in this context. By 'sustainable relationships', we refer to relationships that meet mentees' needs without reducing their opportunities for promoting new insights. A mentee is an individual who is advised, trained, or counselled by a mentor, an experienced and trusted adviser who helps a mentee prepare for the profession. Online studies, which are becoming increasingly common, provide great opportunities for students to become educated. This technology enables fast and efficient communication between students and supervisors as well as allows users to share competences across campuses and national borders. We are facing a paradigm shift in education regarding both the opportunities and challenges of the technological options available today. While the university sector may not have been at the forefront of technological development, a number of online studies are nevertheless currently available to students worldwide.

In order to determine more about the opportunities and challenges associated with guidance, we conversed with a selection of students at our institution and asked questions about the extent to which online guidance can handle the various aspects of supervision. This research is based on a survey conducted among 43 fresh students in primary school teacher education and 31 more experienced teachers who are students in a mentor education program. We chose two such different groups due to our interest in determining
\end{abstract}


whether teacher experience results in differing perceptions of what guidance means for students. What do students consider important regarding effective guidance? Are technological solutions sufficient for knowledge construction? In any guidance context, there exists a relationship, and the relationship concept is central to several of our questions. Our findings reveal that all students prefer a mentor-mentee relationship that includes elements of recognition and warmth.

Keywords: guidance, relations, analogue, digital communication, recognition.

\section{Theoretical Perspectives}

Gregory Bateson (1972) points out that relationships between individuals are fundamental in all forms of communication, and our being part of many different systems is what makes us human:

Communication not only consists of identifiable messages sent back and forth, and of the ever-changing initiatives and responses of dialogue, but also of emotional inner and outer impulses that characterize the relationship, process, change and development of the relationships. Human signs and signals are parts of this process and will probably affect a relation (Eide \& Eide, 2017, p. 76).

We find that the technological revolution we have experienced in recent years has led to a form of division between those who master technology and those who do not. Advisor and former director of the Norwegian Aftenposten Mobile, Anette Mellbye, claims that no industries will be untouched by the technological revolution (Mellbye, 2016), which will favour companies that heavily invest in algorithms, data, and infrastructure. In practice, this means educational institutions can end up in a backwater if one does not choose to hang onto and provide for technology's introduction and development in education.

Geertrui Smedts (2008) argues in an article referenced in Smeyers and Depaepe (2008) that we are technologicalizing the world through everything related to technology:

It is not only the goals that will be determined by technology, but also the means to achieve those goals. I will call this tendency the technological submergence of our lives. This will involve reference to the technology of the society we live in, a condition in which everything is seen in terms of instrumental value (Smedts, 2008, p. 111).

According to Smedts (2008), some others cleverly find a way through the phrase 'paying full attention' within the realm of technology. For example, Lambeir (2004) concludes that we '...must keep alive our imagination about how to use it (ICT) in multiple ways' (p. 310) and 
that we should strive for 'total involvement, or committing one's entire being' (p. 314). Regarding educational relationships, Lambeir (2004) concludes that ICT offers opportunities for 'educational dialogue', arguing that: '... xperimenting with hypertext, websites, virtual design, and online identities contribute to the constitution of the person' (p.355). ICT is from its point of view more than tools.

\section{The Challenges of Technology}

The colonization of practices under educational control means routine, non-educational issues become defined in terms of (lifelong) learning competencies, the acquisition of skills, final attainment levels, learning disabilities, and so on. We shall call this tendency the technological submergence of our lives, which involves reference to the technology of the society within which we live-a condition wherein everything seems to be perceived in terms of instrumental value. Technology's immediately visible impact is that youngsters are perceived as the experts while parents must 'catch up' (Smedts, 2008). In the context of our field, this may imply that young students are experts in technology and we, as mentors, are novices. But what is really included in the guidance concept? We further elucidate this idea below.

\section{Understanding Guidance}

In general, we can assert that guidance is facilitated between many different people with various occupational backgrounds and experience levels. In a teacher education context, guidance must characterize both teaching and practice; in a practical application, this means guidance should be a known and used tool that ensures pedagogical development and growth in mentees. For students, receiving guidance includes both direct meetings and a digital learning platform. With regard to the concept of guidance itself, several definitions are used within the academic environment, and several Norwegian researchers suppose there likely exists no consensus on a definitive definition (Tveiten, 2013). Many individuals who work inside the Norwegian guidance field are well aware of Gunnar Handal and Per Lauvås's (2017) 'action-reflection model', which concerns reflection before, during, and after an action to ensure the mentee receives high-quality development and learning.

Ole Løw (2009) claims guidance is a method of stimulating students for their own learning, defining it as a common term that encompasses counselling, supervision, consultation, mentoring, and coaching. In such a comprehensive definition, guidance is defined within two dimensions: (1) guidance and road searching and (2) answers and questions. Løw (2009) suggests that the term guidance is reserved for the complementary relationship 
between the more experienced and competent and the less experienced and often less competent in a teaching, educational, or vocational context.

In English language literature, the concepts of counselling and supervision are used interchangeably, while consultation, guidance, and mentoring are additionally identified in this field (Butterworth \& Faugier, 1998). The main difference between, for example, counselling, mentoring, supervising, and coaching, may be considered the mentee's freedom to determine his/her own actions without too much external influence.

\section{The Congruent Supervisor}

Carl Rogers (1957) was greatly important for the development of the guidance field and guidance pedagogy at the international level. In Rogers's (1957) theory, recognition and acceptance are some of the most fundamental in the face of the other, which means the mentor sees the mentee as an individual and independent person and thus accepts his attitudes, actions, and narratives. In fact, this concept means accepting and being neither judgemental nor condescending towards others, thus resulting in the mentee's opportunity for self-reflection. For this situation, Rogers draws the following picture: 'If a person can be understood, he or she belongs' (Thorne, 2003, p. 39).

Rogers (1957) raises the concept of unconditionally positive respect, which includes a mentor's warmth and care for a mentee as well as his/her ability to set aside his/her own concerns during the guidance situation. It is necessary that one pay attention to what the other must come by (Rogers, 1957). Taking care of the mentee also requires that the mentor practice empathetic behaviour and consequently be concerned with how the mentee perceives him/her. According to Rogers (1957), when a human experience is understood in a guidance situation, it directly affects the relationship between the mentor and the mentee.

Finally, Rogers (1957) discusses the importance that the mentor be congruent, which we understand as being oneself in a genuine and sincere way in both open-mindedness and presence. The author asserts that when the mentor is genuine and sincere, he may become aware of himself as a human being, which is important when helping others. Eye contact is a practical example of effectively connecting in a conversation, and in guidance situations, it is important that the mentee experience the mentor as trustful, helpful, and sincere.

\section{Relationship Value}

According to Marion Jones (2010), the supervisor must hold a critical understanding of the supervisory role, the potential tensions accompanying such a role, and the capacity for critical self-evaluation. In addition to 
professional and academic knowledge and skills, a tutor requires strong interpersonal evaluation and communication skills as well as emotional intelligence (Jones, 2010; cited in Smith \& Ulvik, 2018, p. 124).

Gregory Bateson (1972) focused his attention on describing relationships rather than individuals or human traits. Bateson spoke warmly about the actions or reactions resulting from the relationships one forms as a human being. In Bateson's (1972) theory, relationships exist very basically between phenomena and between people in all forms of communication. Moreover, communication simultaneously takes place at several levels, which we can understand by considering that a conversation contains content but also concerns an individual's relationship to the content and to the other individual engaging in the conversation. In this sense, we communicate at several levels simultaneously. If we, for instance, raise the understanding of what I communicate to you by one level, then we are concerned with your understanding of my understanding of the conversation's content. In Bateson's (1972) theory, all communication is constantly meta-communicative, meaning we always communicate about content when we communicate about our relationship.

If one supervises a student, then, as a supervisor, one should consider that a manual (guidance manual) has several levels. In the light of the relationship concept, a relationship already exists in that a guidance situation has been established. The relationship's content may depend upon how well the supervisor and the supervised know each other and how their communication is established. It is necessary to be aware that communication involves both verbal and non-verbal aspects. Establishing an effective relationship concerns, for example, the words we use, the questions we ask, and how we present our messages while simultaneously opening up a dialogue. On the other hand, communication is about our body language, such as how we use our eyes, how we use our hands, if one has an open or closed posture, and what kinds of facial expressions match the other party in the guide.

\section{Establishing a Relationship in a Guidance Situation}

In Bjørn Killingmo's (1998) article, the attention is directed to the relationship that is established when two individuals converse, wherein the focus is-among other aspects-drawn to what each individual carries into the conversation. For example, situations may arise wherein an individual who seeks a conversation partner has an agenda that is not perceived by the other. At the same time, the mentor brings with him his values and morals, which can be decisive regarding what kind of guidance he offers. This backdrop can trigger negative energy in the person seeking guidance and thus end in his/her resignation. 
An experienced teacher often possesses knowledge of what works in given situations and can easily give into the temptation of becoming a counsellor based on what is immediately perceived as one's need for guidance. Such attitude can indicate the importance of both listening to what is spoken and at the same time studying the other's body language to decipher the message. By concluding too quickly, the supervisor is at risk of becoming one who limits a student's creativity rather than opening up new and alternative solutions. In order for the dialogue to be fruitful and produce the best possible result, it is necessary that the mentee experience security and recognition; in this context, recognition with others is a key concept. Axel Honneth (1992) claims that the development of personal identity requires the experience of recognition. Honneth (1992) describes various arenas for recognition, including close relationships, the legal sphere, and social contexts. The legal sphere is what we experience when we enter society and meet laws, rules, and regulations that establish various opportunities, limitations, and rights. The social sphere involves valuation, in which we experience responses to positive attributes, contribute to public benefit, and experience ourselves as individuals. We highlight four essential elements in relation to the recognition concept: to be seen, to be listened to, to understand, and to receive confirmation. In order for a human to experience recognition and experience as a subject, Honneth (1992) asserts that these four elements are fundamental (Schibbye, 2004).

Recognized Norwegian psychologist Dag $\emptyset$. Nordanger discusses the importance of interpersonal competence in therapeutic meetings and highlights the strength that lies in the therapist-patient alliance (Nordanger, 2018). We should briefly point out that a guidance conversation is not a therapeutic situation, although many common features deal with relationships in the various meetings between someone who needs help and someone who wants to help. Nordanger promotes an interesting question by wondering why some therapists fail with most patients while others achieve success with almost everyone they get in contact with, despite their use of the same therapy method. Nordanger (2018) believes this is largely about the relationship's power and emphasizes the importance of establishing an effective relationship characterized by empathy, flexibility, cooperation, and understanding.

Danish philosopher Knud Løgstup (1991) highlights the caring perspective when describing offering something of one's own to the other during a meeting and therefore having more or less of the other's life in one's hand; this again implies that, according to Løgstrup, every single meeting between individuals in this way represents valuable diversity. In a guidance situation or in a counselling interview, this perspective means 
one has a piece of the other's life in one's hands; if one guides another, what one says and does will affect the other in some way. One important consideration is that the words one uses - both positive and negative - can be remembered for the rest of another's life.

\section{Previous Research}

Previous research on effective guidance points to the needs that characterize newly educated teachers as well as what characterizes effective guidance through the planning and use of strategic tools (Lejonberg \& Føinum, 2018). We nevertheless fail to pay adequate attention to the interpersonal perspective based on a mentor's relationship competence and the direct meeting between teacher and student, which is in our context referred to as mentor and mentee. Experience suggests that effective tools and professional knowledge do not help if the mentor's ability to establish a strong relationship is absent.

Many have written about the relationship's importance in the guidance context. Norwegian researchers Grete Haugan, Eva Aigeltinger, and Venke Sørlie (2012) published an article in Norwegian journal Sykepleien, in which they point out that students '...may have unrealistic notions that supervisors basically know what appropriate responsibility for the student is' (p. 11). The authors mention that responsibility also concerns one's demonstration of confidence, trust, and effective relationships.

A strong picture of what matters in a guidance situation is Lambert's Pie (Asay \& Lambert, 1999), which is a model based on research supporting that the following factors affect guidance: 'Technique and model factors $15 \%$, expectancy and placebo effects 15\%, The therapeutic relationship $30 \%$, Client variables and extra therapeutic events 40\%' (Asay \& Lambert, 1999; Cooper, 2008, p. 56). Based on this model, we can determine that the relationship between the supervisor and road applicant in a counselling conversation possesses significant meaning and concerns expectations, past experiences in similar situations, and techniques or methodologies used while the two parties converse.

In a quantitative study conducted by Norwegian researcher Eli Lejonberg (2016), lector students' assessments of guidance in practice were investigated. They evaluated their own teaching skills and experiences of trust during guidance situations, emphasizing the importance of receiving clear feedback on the guidance situations. In terms of relationships, the findings revealed that the lecturers' ability to obtain their degrees was highlight dependent upon trust between them and their mentees. An interesting finding from the survey indicated that the students who considered their mentors' competence to be high also had greater faith in their own abilities as teachers. Conversely, the study says little about what 
creates an effective mentor-mentee relationship and what can contribute towards creating trust and security in a guidance situation. Through our research, we wish to highlight what students believe we, as mentors, should be aware of during guidance situations.

\section{Methodological Design}

Our research is based on a qualitative study in which where we are interested in determining students' thoughts about the factors at play and the relationship's importance in the guidance context. We believe there exists an underlying hypothesis that claims the relationship between the mentor and mentee is important.

This study deals with action practice without the practice itself (guidance) being the subject of research; such cases can be classified as a phenomenological approach (Creswell, 1998; Postholm, 2010, p. 17). Postholm refers to Moustaka (1994), who claims that '...the main purpose of phenomenological research is to understand meaningful, concrete relationships that are present in a specific situation or a specific context' (cited in Postholm, 2010, p. 43). These observations cannot be made by the researcher, yet the experiences are not forgotten by those who have experienced them; thus, experiences may be obtained by talking to participants (Postholm, 2010, p. 43). In order to answer our research questions, we studied two groups of students, one of which constitutes firstyear students (43) in teacher education and the other of which constitutes students enrolled in mentor education (31). To obtain data, we developed a questionnaire with the following variables: age, gender, knowledge, proximity/distance, relationship/relationship skills, and educational level. Furthermore, we discuss our data through a socio-cultural perspective in light of the theory of relationships, recognition, and communication.

\section{Findings in the Data Material}

The data reveal that many interviewees believe knowing one's mentor is important, while the extent to which one knows one's mentor was not brought up as a concern. Specifically, 42 percent of the young participants (younger than 30 years) believe this factor is greatly important, while merely 4 percent of the older participants (older than 30 years) who have more experience believe this factor to be greatly significant.

The mentor's age is considered less important for one to experience effective guidance. Nearly 80 percent of all participants claimed that age has no or little significance, and computer material also demonstrates that the mentor's gender typically does not affect the counselling situation in a positive or negative way. Among the younger students, however, 
55 percent believe gender can at times affect how the mentee experiences guidance, although this variable's significance was not elaborated upon.

The mentor's education level may affect the guidance situation's yield. For this variable, 46 percent of participants claimed that education is quite significant, while 35 percent believe education is only somewhat significant. Interestingly, 40 percent of those who believe education is quite significant include students younger than age 30, while 20 percent of those in this group believe education is somewhat significant. Among the most experienced students, none believe the mentor's education level is greatly important regarding his/her supervision, but most agree that education level has some significance.

When it comes to questions about guidance and whether or not a conversation is affected by the mentor-mentee relationship, the participants' responses were divided between somewhat significant and greatly significant; their responses are italicized in the text below. Of all respondents, 58 percent answered that the relationship was of great importance, while 40 percent responded that the relationship had some significance. No participants believe the relationship does not matter at all, but one respondent believes the relationship holds little significance. Herein, a significant correspondence thus exists between what the young students believe and what the older students with more experience believe. If we consider this in light of the mentor's possession of relationship competence, 56 percent perceive this variable as very important, while 40 percent perceive it as somewhat important. A total of 60 percent claimed it is greatly important that the mentor establish an effective relationship during the first meeting with his/her mentee, while no respondents believe this variable is entirely unimportant.

In total, 71 percent of the informants believe it is somewhat important that the mentor balance between proximity and distance during a manual call, while 26 percent believe this variable to be very important and none believe it to be entirely unimportant. In the survey, no guidelines were established regarding what the informants should understand about proximity and distance; rather, they interpreted their beliefs based of their own standpoints and professional knowledge.

In the questionnaire's open box concerning what they believe distinguishes an effective relationship and what constitutes relationship competence, about half of the young participants responded that security, the mentor shows respect for the mentee, and the mentor has an understanding of what the mentee is talking about are important factors. Several students mentioned being shown trust as a significant factor in the guidance context, while other dimensions mentioned by several of the oldest respondents in this same area include the importance of openness and honesty as well as 
mutual respect. These participants believe it is correlated with the mentor's allotment of sufficient time and possession of a sincere desire to want to help the other. In this context, the participants also mentioned that clarification regarding the actual guidance situation's expectations lays a strong foundation for one who is seeking such an effective relationship. Many students highlight the importance of recognition in that the mentor should be supportive and the mentee must be allowed to make mistakes. The mentor must show understanding and see the individual's needs. In situations wherein road searches are unsafe, the mentor must show empathy and show interest in the individual's needs. In addition, the mentor must be gentle, attentive, sociable, caring, honest, sincere, committed, and must combine the academic and the social. These qualities are expressed through a dialogic communication.

The participants highlighted body language as essential in communication in that smiling and nodding along during conversation should be included in the feedback. Several students highlighted the mentor's ability to listen and have a sense of humour, while many others mentioned that the mentor must maintain eye contact and use the student's name. One participant reported that the guidance situation should be perceived as equitable even if it is asymmetric. Several informants claimed that the mentor and mentee must be active, and the students hold the clear expectation that the mentor should be willing to teach and guide the mentee in a positive direction. The mentor's feedback must be characterized by confidence, trust, and the affordance of mistakes. Several students mentioned that the mentor must be willing to help, and by extension, several students believe there must be mutual respect and the mentee must experience recognition. Students in both groups highlighted the importance of showing sincere interest expressed through looks, acknowledging nodding and questioning on the part of the mentor. One participant mentioned that it is greatly important for the mentee to be recognized as a person, while several mentioned generosity as an element that should characterize the guidance situation while simultaneously holding the expectation of receiving from the mentor a combination of academic and social knowledge.

\section{Discussion}

\section{Discoveries and Challenges of Guidance}

Our survey confirms that relationships and relationship building are greatly significant regarding one's experience of effective guidance. For direct questions, as many as 58 percent of the respondents believe an effective relationship is greatly important, while 34 percent believe such a relationship is somewhat important. This result closely aligns with 
the theory we highlighted earlier on that indicates relationships are important. The knowledge also provides a starting point for considering it important that relationship competence be included in the guidance context in both the teacher education programs and the guidance education programs. This consideration indicates that both mentors and students should know how to build effective relationships and how relationship competence can be practiced. A considerable amount of research (e.g., Hattie, 2017; Drugli, 2013; Nordahl, 2002) highlights the importance of relationships between teachers and pupils, which is a relationship additionally highlighted by the majority of students in our data. Elements of importance in building relationships were also highlighted, such as mutual respect, trust, openness, honesty, and an appreciative attitude. Our results demonstrate that certain challenges are presented to students when they are expected to experience these variables exclusively through digital guidance, although Lambeir (2004) argues that ICT offers opportunities for 'educational dialogue'. Although such a dialogue may be held, much of what is valid in the relationship and important in the guidance context are nevertheless marginally present.

Schibbye (2004) claims that recognition is something you have to develop, as an attitude, throughout the whole life. In this vein, what then happens when two mentors use the same words and have positive body language but are experienced differently by those who are guided? Killingmo (1998) touches upon this circumstance by focusing on what the mentor and mentee each bring into the relationship-be that experiences from previous guidance situations or simply the expectations of what benefit such situations should contribute, which is perhaps a consideration we might learn during our dealings with students. We must clarify what expectations both students and mentors hold for the guidance context, and these expectations can be clarified along different levels: on one hand, the expectation of a mentor's help in solving a task, while on the other hand, the expectation that one will become a safer student who supports one's views. The guidance situation's function is, among other things, to stimulate a student's learning (Løw, 2009), and the mentormentee relationship can be decisive for the amount of guidance provided to the mentee. Nordanger (2018) discusses the meaning of force and points to the importance of establishing an effective relationship characterized by empathy, flexibility, cooperation, and understanding.

In total, 95 percent of the young students believe knowing their mentor is greatly important. In addition, many wrote in their commentaries that security, trust, and being seen and listened to are essential features of an effective relationship. Students at the primary and lower secondary levels often head straight into upper secondary education and into an 
academic environment. They experience an academic tradition in which they must argue their views and opinions, are required to critically reflect their research-based knowledge, and must make their assertions based on research from the field. It is essential that the mentor be confident in the role if one is to meet the student where he/she currently stands and not where he/she wishes to be. Schibbye (2004) argues for a subject-subject relationship in the guiding context, meaning the mentee should be met with an open-minded attitude, such as 'I wonder what you are thinking about', rather than a subject-object attitude, such as 'you must admit that what was not so wise', or a similar attitude in which the mentor points out when the mentee acts or says something against the mentor's expectations.

On one hand, defining an action or perspective in this way is characterized by Schibbye (2004) as relational abuse; on the other hand, a young student may expect specific advice from his/her mentor, who possesses knowledge of a particular situation from teachers practice. In such situations, it is also essential that the mentor and mentee discuss what guidance actually constitutes in order to help the counsellor find the way on his/her own. This point implies that we, as mentors, should be cautious when giving advice, but on the other hand, mentees may themselves, request advice from their mentors.

Several informants in our study express that an effective relationship is characterized by dialogue, active communication, considerable involvement and a body language that reflects positive attitude. Through mentors implementation of open-ended questions the mentee may for example reflect upon whether the solution or method was effective or ineffective, as well as what might be handled differently in a similar future situation. Rogers (1957) supports that we should acknowledge what the other individual in the conversation offers by expressing respect and accepting. This process is not always necessarily easy because the mentor brings his knowledge and cultural landscape into the guidance situation, while the mentee might bring an opposing perspective. Consciously or unconsciously, the mentor is characterized by his past experiences and ideas and who he/she is as a human being. According to Rogers (1957), it is important that the mentor exhibit his/her unconditionally positive consideration by setting aside his/ her own thoughts and experiences and having the mentee fully in focus. On one hand when the mentor meets his/her mentee, he/she will establish given frameworks and guidelines, while on the other hand, the meeting will be characterized by the values and attitudes from both parts. This shows some of the complexity in guidance, and we cannot exclude the interpersonal perspective, which Nordanger (2018) believes may be of absolute importance for mentors to succeed as 'helpers' and contribute to their mentees' continued learning. A key question is therefore whether or 
not technology can sufficiently safeguard the guidance. As researchers we are sceptical about technology`s effectiveness, yet at the same time believe it is important to meet today's young people in their arenas and implement tools that may ensure we reach as many learners as possible.

\section{Guidance in Practice}

A central element for those who are engaged in teacher educationwhether that be basic or higher education-is that we meet our students with the knowledge of the importance of the relationships. Perhaps new students must actually learn to receive guidance, and the answers the 'freshest' students give may indicate that they are much more concerned with security, honesty, and patience than are their older counterparts.

If we are to succeed in strengthening students' self-experiences, guidance situations must be characterized by recognition. Rogers (1957) asserts that recognition and acceptance are some of the most fundamental in the face of the other. It is evident from our data that a reputable and understanding mentor is one variable that students consider in the description of an effective relationship. Perhaps not so surprising but nevertheless no less important is our observation that the recognition and establishment of positive self-experiences are prerequisites for building effective guidance situations. Listening both verbally and non-verbally to mentees by nodding or using small words was emphasized as important by several informants in our study. The mentor's attention directed towards the mentee by actively listening facilitates the latter's experience of being seen and cared about, and thus a mentor being genuinely present for his/her mentee during a meeting is therefore greatly important for the mentee's positive experience while seeking help. In addition to listening, it is important that the mentor ask thoughtful questions that make the mentee think, reflect and go ahead. The mentor role's complexity requires that one balance many thoughts at one time, especially while one is busy providing professional guidance in teacher education. In the future, for our part, balancing analogue and digital meetings will ensure the best possible growth and development for our future generation of teachers.

\section{References}

Asay, T. P., \& Lambert, M. J. (1999). The empirical case for the common factors in therapy: Quantitative findings. In M. Hubble, B. L. Duncan, \& S. D. Miller (Eds.), The heart and soul of change: What works in therapy (pp. 351-357). Washington, DC, US: The American Psychological Association.

Bateson, G. (1972). Steps to an ecology of mind. New York, NY, US: Ballantine.

Butterworth, T., \& Faugier, J. (1998). Clinical supervision and mentorship in nursing. London: Stanley Thornes Ltd. 
Cooper, M. (2008). Essential research finding in counseling and psychotherapy: The facts are friendly. London: SAGE Publications.

Creswell, J. W. (1998). Qualitative inquiry and research design: Choosing among five traditions. Thousand Oaks, CA, US: SAGE Publications.

Driscoll, J. (2000). Practicing clinical supervision. Edinburgh: Bailliere Tindall.

Drugli, M. B. (2013). The relationship is a teacher and student of doing the pupils' learning and well-being. Oslo, Norway: Cappelen Damm.

Rambøll. (2016). Veiledning av nyutdannede barnehagelorere og loerere: en evaluering av veiledningsordningen og veilederutdanningen [Mentoring of newly-educated kindergarten teachers and teachers: an evaluation of the mentoring scheme and mentor education]. Retrieved from https://www.udir.no/globalassets/filer/tall-og-forskning/ rapporter/2016/evaluering-av-veiledningsordningen-sluttrapport.pdf.

Eide, H., \& Eide, T. (2017). Communication in relationships. Person orientation, interaction, ethics. Oslo, Norway: Gyldendal Akademisk.

Hattie, J. (2017). Visible learning for teachers. Oslo, Norway: Cappelen Damm.

Haugan, G., Aigeltinger, E., \& Sørlie, V. (2012). Challenges to guide nursing students in practice studies [Online]. Nursing. Retrieved from https://static.sykepleien.no/sites/ default/files/documents/forsknings/898972.pdf?c $=1410453150$.

Honneth, A. (1992). Kampf um anerkennung: Zur moralischen Grammatik sozialer konflikte (The struggle for recognition: The moral grammar of social conflicts). Frankfurt, Germany: Suhrkamp Verlag.

Jones, M. (2010). Supervision of new teachers. In K. Smith \& M. Ulvik (Eds.), In Veiledning av nye laerere. Oslo, Norway: Universitetsforlaget.

Killingmo, B. (1998). The opening conversation [Unpublished master thesis]. Oslo, Norway: University of Oslo.

Lamb, B. (2004). The educational cyberspace affair. A philosophical reading of the relevance of information and communications technology for educational theory [Unpublished doctoral dissertation]. Leuven, Belgium: KU Leuven, Department of Pedagogical Sciences.

Lauvås, P., \& Handal, G. (2017). Guidance and practical occupational theory (3 ${ }^{\text {rd }}$ ed.). Oslo, Norway: Cappelen Damm.

Lejonberg, E. (2016). What can contribute to good guidance? Oslo, Norway: University of Oslo. Faculty of Educational Sciences.

Lejonberg, E., \& Føinum, M. (2018). What is good guidance? Bergen, Norway: Fagbokforlaget.

Løgstrup, K. E. (1991). The ethical claim. Oslo, Norway: Gyldendal.

Løw, O. (2009). Praksisveilederen I skolen. Pressbooks. Copenhagen, Denmark: Academic publisher.

Mead, G. H. (1934). Mind, self, and society from the standpoint of a social behaviorist. Chicago, IL, US: University of Chicago Press.

Mellbye, A. (2016). No industry will remain untouched by the technological revolution [Online]. Aftenposten. Retrieved from https://www.aftenposten.no/kultur/i/GM54/ Ingen-bransjer-vil-forbli-uberort-av-den-teknologiske-revolusjonen. 
Nordahl, T. (2002). Teacher student relationship [Online]. Retrieved from http:// www.voldaskulen.no/web/NettskoleRessurs.axd?id =0b800bd3-98c1-43bc-a6f66e87f11bad0a.

Nordanger, D. Ø. (2018). The power of relationships [Online]. Psykologisk.no. Retrieved from https://psykologisk.no/2018/11/relasjonens-kraft-i-terapi/.

Postholm, M. B. (2010). Qualitative method an introduction focusing on phenomenology, ethnography and case studies. Oslo, Norway: Universitetsforlaget.

Rogers, C. R. (1957). The necessary and sufficient conditions of therapeutic change. Journal of Consulting Psychology, 21(2), 95-103.

Schibbye, A. L. L. (2004). The good dialogue. I School Psychology No 2. year 39. Pp. 3-15.

Schibbye, A. L. L. (2009). Relationships: A dialectical perspective on existential and psychodynamic psychotherapy ( $2^{\text {nd }}$ ed.). Oslo, Norway: Universitetsforlaget.

Sjøberg, J. (2015). One in three Norwegian jobs can be digitized [Online]. Aftenposten. Retrieved from https://www.aftenposten.no/okonomi/i/ymqA/n-av-trenorske-jobber-kan-bli-digitalized.

Skagen, K. (2013). In the landscape of the guide. Oslo: Cappelen Damm.

Smedts, G. (2008). Dipping into the technological submergence of education. In P. Smeyers \& P. Depape (Eds.), Educational research: The educationalization of social problems (pp. 106-123). Location: Springer.

Smith, K., \& Ulvik, M. (2018). Guidance of new teachers. National and international perspectives ( $2^{\text {nd }}$ ed.). Oslo, Norway: Universitetsforlaget.

Teigen, V. R. (2015). It lived the body's place in counseling. In R. Kvalsund \& C. Fikse (Eds.), Rådgivingsvitenskap. Helhetlige rådgivingsprosesser, relasjonsdynamikk, vekst, utvikling og mangfold. (Counseling science. Comprehensive counseling processes, relationship dynamics, growth, development and diversity) (pp. 145-164). Bergen, Norway: Fagbokforlaget.

Thorne, B. (2003). Carl Rogers ( $2^{\text {nd }}$ ed.). London: SAGE Publications.

Tveiten, S. (2013). Guidance - More than words. Bergen, Norway: Fagbokforlaget.

Ulleberg. I. (2014). Communication in guidance. Oslo, Norway: Universitetsforlaget. 